\title{
Covid-19 Perception of Senior Nursing Students and their Behaviours Regarding Coping with Stress
}

\author{
Gamze Akay ${ }^{*}$ (D) and Türkan Kadiroğlu² (D) \\ ${ }^{1}$ School of Health Services, Artvin Çoruh University, Artvin, Turkey \\ ${ }^{2}$ Pediatric Nursing, School of Nursing, Ataturk University, Erzurum, Turkey
}

*Corresponding author: Gamze Akay, Lecturer, School of Health Services, Artvin Çoruh University, Artvin, Turkey, Tel: +90-(466)-215-10-82/6016

\begin{abstract}
Background: Nursing students are exposed to more stress compared to the stress factors other students during the life of university.In Turkey during the Covid-19 pandemic, nursing students encountered a new reality of that includes fear of infection, the challenges of distance education and more. Therefore post-graduation plans of nursing students may change and students may find themselves at higher risk of infection.
\end{abstract}

Aim: The aim of this study is to examine Covid-19 perception of senior nursing students and their behaviours regarding coping with stress.

Material and Method: The population of this research which is descriptive consists of final year students who receive education in the department of nursing of two state universities. The study was conducted with the entire population. Data were collected using the Introductory Information Form, Covid-19 Perception Form, and Stress Coping Behaviour Scale for Nursing Students.

Results: It has been found that approximately half of the students thought that the Covid-19 virus was a biological weapon, and the majority of them thought that Covid-19 would cause economic crises; however, Covid-19 developed a culture of hygiene and cleaning in the society. It has been also determined that the stress coping behaviours of the students were moderate during Covid-19 pandemic; being optimistic, transference and problem solving levels were moderate while the avoidance level was above the average.

Conclusion: Senior nursing students think that Covid-19 is positively affects the social hygiene culture. In addition, the importance of personal measures in the protection against Covid-19 and the possibility of implementing these measures were determined in nursing students.

\section{Keywords}

Covid-19, Nursing students, Stress

\section{Introduction}

Covid-19 quickly became a global health threat and was classified as a pandemic by the World Health Organization [1,2]. WHO accepts pandemics as a major risk for international health [2]. Due to the relatively high contagious and deadly nature of Covid-19, measures that have been taken both in the world, and Turkey pose a risk to the mental health of individuals [3]. Factors such as how long Covid-19 will last, its results, and uncertainties in our level of being affected increase the stress of individuals, especially those who provide or will provide health care [4].

In pandemics such as Covid-19, while the risk of being infected by individuals is quite high, while the healthcare staff working in the risky units of hospitals is even higher [5]. This situation can cause many psychological problems in healthcare professionals. Through conducted studies, the psychological effects of pandemics have been proved to be related to occupational groups $[5,6]$. It is known that the most affected occupational group is nursing [7].

In a study conducted on the mental health of healthcare professionals working in hospitals during the Covid-19 pandemic process in China, it was found that nurses had more psychological symptoms than physicians while females had more psychological symptoms compared to males [8]. Similarly, it was determined that nurses had more psychosocial symptoms than physicians while females had more psychosocial symptoms compared to males in studies

Citation: Akay G, Kadiroğlu T (2021) Covid-19 Perception of Senior Nursing Students and their Behaviours Regarding Coping with Stress. Int Arch Nurs Health Care 7:161. doi.org/10.23937/24695823/1510161

Accepted: June 26, 2021: Published: June 28, 2021

Copyright: (C) 2021 Akay G, et al. This is an open-access article distributed under the terms of the Creative Commons Attribution License, which permits unrestricted use, distribution, and reproduction in any medium, provided the original author and source are credited. 
that were conducted to determine the psychosocial effects of SARS on healthcare personnel $[6,7]$. The fear of being infected in nurses of which the majority consists of women is higher than the other individuals of the society $[9,10]$. The biggest reason for their fear is not due to being exposed to the virus themselves, but to infect their families or those with whom they have close relationships [11].

Nursing students are exposed to more stress compared to the stress factors other students during the pandemic process [12]. One of the stress factors is that nursing students do their internships and practical courses in hospital environments. Students experienced intense stress and anxiety during the pandemic process, as they conducted their courses and exams through distance learning, and they were unable to perform clinical practice [13]. A study examined the difficulties experienced by nursing students during the pandemic and found that students could not keep up with distance education lessons, so they could not cope with the anxiety they experienced [13]. A study conducted in China found that college students who lived in the rural area during the pandemic and had a poor income status experienced more anxiety [14]. Moreover, during the pandemic process, students' efforts and anxiety to protect themselves from the disease also negatively affected their ability to concentrate on courses and their mental health [14-16]. One of the biggest stress sources of students is their post-graduation plans [17]. During the Covid-19 pandemic, post-graduation plans of nursing students may change and students may find themselves at higher risk of infection [17]. Nursing students do not want to work in health institutions with insufficient infection policies while performing their profession [18]. Therefore, it is thought that the stress level will be higher in senior nursing students who will graduate in a short period [14,19].

This research was carried out to determine Covid-19 perception of the nursing students and their behaviours regarding coping with stress.

Here are its research questions:

1) How do senior nursing students perceive Covid-19?

2) What are the stress coping behaviors of senior nursing students?

3) What are the factors affecting the stress coping behaviors of senior nursing students?

\section{Methods}

\section{Design}

This research was carried out in descriptive type.

\section{Participants}

The research was conducted with senior nursing students in faculties of two state universities which are located in the Black Sea and Eastern Anatolia region of Turkey and which offer a 4-year undergraduate nursing education between April 20, 2020, and June 1, 2020. The population of the research consisted of final year nursing students who receive education in the related faculties during the spring semester of 2019-2020 academic year. In the research, the whole population was tried to be reached without using the sampling method $(N=320)$. The questionnaire response rate was $86.5 \%(N=277)$.

\section{Procedure}

This study was approved by Research Ethics Committee of Artvin Coruh University (Number: E.4886, Date: 15.04.2020) and Scientific Research Platform of the T.R. Ministry of Health.Data collection tools were delivered to students online via the data collection link which was created using a survey website called surveey.com. In the meantime, the data collection link was sent to the students via message and mail through the student affairs unit of the faculty after obtaining permission from the relevant institutions. With the encryption of the survey, repeated attempts to the research were prevented. In both stages of the research, access to the data collection link was provided for 14 days between the dates of the research stages. Access to the data collection link was then prohibited. In the research, it took 15-20 minutes to fill in the Introductory Information Form, Covid-19 Perception Form, and the Stress Coping Behaviour Scale for Nursing Students (SCBSNS).The questionnaires were collected from April 20 to June 1, 2020.

\section{Instruments}

The data of the study were obtained through the Introductory Information Form, Covid-19 Perception Form and the Stress Coping Behaviour Scale Form for Nursing Students.

\section{Introductory information form}

This form, which was prepared by the researchers, consisted of 4 questions regarding the nursing students' age, gender, income status, and love towards nursing. In this question form, nursing seniors were asked 10 questions about the perception of Covid-19. These 10 questions were created by researchers based on the current situation related to the Covid-19 pandemic process and by reviewing the literature. These items reflect the feelings, thoughts, predictions and ideas of nursing seniors about the pandemic process. In order to determine whether the question form created represents the situation to be measured and whether it is suitable for the purpose of the study, the content validity was tested by considering expert opinion. For this purpose, opinions were obtained from four experts in the field of nursing and two psychiatrists. The question form was sent to the experts via e-mail, and the experts were informed by the researchers about the relevant 
concepts. Experts were asked to rate the intelligibility of each substance on a scale rated between 1 and 4 and whether it measured the pandemic process. Items on this scale were rated as 1 "not suitable", 2 "needs to be made suitable", 3 "suitable but needs minor changes" and 4 "very suitable". The level of consonance of expert opinions was calculated using the $W$ analysis of the nonparametric test Kendall. The scores given by the experts were not statistically different (Kendall $w=$ $0.355 ; p>0.05$ ) and there was consensus. Therefore, the scope reliability of these items was provided for the students [20].

\section{Covid-19 perception form}

This form, which was prepared by the researchers, consisted of 10 questions related to the nursing students' perception of Covid-19. Responses to the questions in this form areas follow: 1 = agree, 2 = neither agree nor disagree and 3 = disagree.

\section{Stress coping behaviour scale for nursing students (SCBSNS)}

Stress Coping Behaviour Scale for Nursing Students was developed by Sheu, et al. in Chinese [21]. Turkish adaptation of the scale was made by Karaca, et al. [22]. The scale consists of 19 items divided into four subscales. Responses to the scale which is a five-point Likert type scale is as follows: " 1 = Strongly disagree, 2 = Disagree, 3 $=$ Neither agree nor disagree, $4=$ Agree and $5=$ Strongly agree". The subscales are being optimistic (items 1, 2, 6 and 8), transference (items 4, 5 and 13), problem solving (items $3,7,9,10,11$ and 12) and avoidance (items 14,15,16,17, 18, and 19). A higher score in one factor indicated more frequent use of this type of coping behaviour. The Cronbach's alpha coefficients for the problem solving and avoidance sub-dimensions of the scale were found to be (0.57-0.84), and the Cronbach's alpha coefficients for the sub-dimensions of staying optimistic and transferring (0.04-0.40). In the study of Karaca, et al., the internal reliability coefficient Cronbach's alpha was 0.76 .

\section{Data analysis}

IBM SPSS AMOS Statistics for Windows, (Version23.0; Armonk, New York) program was used to evaluate the data. In the study, unit numbers (n), percentage (\%), mean \pm standard deviation ( $\bar{x} \pm s s)$, minimum and maximum values were provided as descriptive statistics. The level of agreement of the expert opinions was determined using the non-parametric test Kendall's W analysis. Mann-Whitney $U$ test and Kruskal-Wallis test were used for comparisons. The results were assessed at a 95\% confidence interval, and the threshold for statistical significance was $p<0.05$.

\section{Ethics}

Ethics committee approval, institutional permission,
Table 1: Distribution of some socio-demographic characteristics of students $(\mathrm{N}=277)$.

\begin{tabular}{|l|l|l|}
\hline Characteristics & $\mathbf{n}$ & $\%$ \\
\hline Age ${ }^{*} 22.30 \pm 1.78$ (Min:19-Max: 30) & \multicolumn{2}{l|}{} \\
\hline Gender & \multicolumn{2}{l|}{} \\
\hline Female & 219 & 79.1 \\
\hline Male & 58 & 20.9 \\
\hline Income Status & & \\
\hline Income more than expenditure & 48 & 17.3 \\
\hline Income and expenditure equivalent & 215 & 77.6 \\
\hline Expenditure less than income & 14 & 5.1 \\
\hline Love towards Nursing & & \\
\hline Yes & 243 & 87.7 \\
\hline No & 34 & 12.3 \\
\hline
\end{tabular}

${ }^{*} \mathrm{X} \pm \mathrm{SS}$ was stated as (Min-Max).

and online informed consent from the students who participated in the research were obtained for the research. In the study, the principles of the Helsinki Declaration were adhered to.

\section{Results}

It was determined that the average age of the students who participated in the study was $22.30 \pm$ $1.78(\min =19, \max =30), 79.1 \%$ were women, $77.6 \%$ perceived that their income and expenditure are equivalent, $87.7 \%$ liked their profession (Table 1).

$46.6 \%$ of nursing students think that that this virus has occurred as a biological weapon and $86.6 \%$ think that economic crises will. While $56.7 \%$ stated that traditional medicines will be effective for protection against this virus, $61.4 \%$ believe that a treatment method will be discovered within this year. $89.9 \%$ think that the cleaning culture is developing in the society, $52.7 \%$ believe that the information gained from social media is useful. While $52.3 \%$ believe that health-related measures taken in our country are sufficient while $52 \%$ believe that health-related measures taken in their schools are sufficient. While $65.3 \%$ think that personal measures will protect against this virus, $89.9 \%$ state that they will apply the suggested measures (Table 2).

When the relationship between the sociodemographic characteristics of the students and the mean scores of the SCBSNS and its sub-dimensions were examined; it was determined that the sub-dimension of being optimistic of the students whose income is less than their expenses is more significant than the students whose income is equal to their expenses and whose income is more than their expenses $(p<0.005)$. It was determined that the SCBSNS avoidance sub-dimension was more significant in senior nursing students whose income was higher than their expenses than the students whose income was equal to their expenses and whose income was less than their expenses ( $p>0.05$ ) (Table 3$)$. 
Table 2: Distribution of nursing students' perception regarding Covid-19 ( $=277)$.

\begin{tabular}{|l|l|l|}
\hline Perception Regarding Covid-19 & N & $\%$ \\
\hline This virus is a biological weapon & 129 & 46.6 \\
\hline Agree & 71 & 25.6 \\
\hline Neither agree nor disagree & 77 & 27.8 \\
\hline Disagree & & \\
\hline This virus causes economic crises & 240 & 86.6 \\
\hline Agree & 25 & 9.0 \\
\hline Neither agree nor disagree & 12 & 4.3 \\
\hline Disagree & & \\
\hline $\begin{array}{l}\text { Traditional medicines are effective for } \\
\text { protection against this virus }\end{array}$ & 157 & 56.7 \\
\hline Agree & 71 & 25.6 \\
\hline Neither agree nor disagree & 49 & 17.7 \\
\hline Disagree & & \\
\hline $\begin{array}{l}\text { Treatment method will be discovered } \\
\text { within this year }\end{array}$ & 170 & 61.4 \\
\hline Agree & 57 & 20.6 \\
\hline Neither agree nor disagree & 50 & 18.1 \\
\hline Disagree & & \\
\hline It improves the culture of cleaning in the \\
community & & 69.9 \\
\hline Agree & & \\
\hline Neither agree nor disagree & & \\
\hline
\end{tabular}

Disagree

The information I obtain from social media is useful

Agree

Neither agree nor disagree

Disagree

9

3.2

Health-related measures taken in our country are sufficient

Agree

Neither agree nor disagree

79

Disagree

53

52.3

Health-related measures taken at our school are sufficient

Agree

Neither agree nor disagree

Disagree

\begin{tabular}{|l|l|}
\hline 146 & 52.7 \\
\hline 80 & 28.9 \\
\hline 51 & 18.4 \\
\hline
\end{tabular}

Personal measures protect us against this virus

Agree

$181 \quad 65.3$

Neither agree nor disagree

\begin{tabular}{l|l}
67 & 24.2
\end{tabular}

Disagree

\begin{tabular}{l|l}
29 & 10.5
\end{tabular}

I apply the suggested measures

Agree

$249 \quad 89.9$

Neither agree nor disagree

Disagree

\begin{tabular}{|l|l|}
\hline 21 & 7.6 \\
\hline 7 & 2.5 \\
\hline
\end{tabular}

Table 3: Comparison of the socio-demographic characteristics of the students and the average points of the SCBSNS and subscales $(\mathrm{N}=277)$.

\begin{tabular}{|c|c|c|c|c|c|c|c|}
\hline \multirow[t]{2}{*}{ Özellikler } & \multirow[t]{2}{*}{$\mathbf{n}$} & \multirow[t]{2}{*}{$\%$} & $\begin{array}{l}\text { Being } \\
\text { Optimistic }\end{array}$ & Transference & $\begin{array}{l}\text { Problem } \\
\text { Solving }\end{array}$ & Avoidance & Total \\
\hline & & & $X \pm S D$ & $X \pm S D$ & $X \pm S D$ & $X \pm S D$ & $X \pm S D$ \\
\hline \multicolumn{8}{|l|}{ Gender } \\
\hline Female & 219 & 79.1 & $7.02 \pm 2.59$ & $7.53 \pm 1.63$ & $11.45 \pm 2.63$ & $17.07 \pm 3.36$ & $43.07 \pm 6.40$ \\
\hline Male & 58 & 20.9 & $7.18 \pm 2.73$ & $7.62 \pm 1.94$ & $12.06 \pm 2.97$ & $17.36 \pm 3.29$ & $44.27 \pm 6.86$ \\
\hline Test and $p$ & & & $\begin{array}{l}U=6175.000 \\
p=0.744\end{array}$ & $\begin{array}{l}U=6187.500 \\
p=0.758\end{array}$ & $\begin{array}{l}U=5710.500 \\
p=0.235\end{array}$ & $\begin{array}{l}U=6086.500 \\
p=0.624\end{array}$ & $\begin{array}{l}U=5743.500 \\
p=0.262\end{array}$ \\
\hline \multicolumn{8}{|l|}{ Income Status } \\
\hline $\begin{array}{l}\text { Income more than } \\
\text { expenditure }\end{array}$ & 48 & 17.3 & $5.57 \pm 2.63$ & $7.87 \pm 1.86$ & $11.35 \pm 2.96$ & $18.12 \pm 3.21$ & $43.02 \pm 6.47$ \\
\hline $\begin{array}{l}\text { Income and } \\
\text { expenditure } \\
\text { equivalent }\end{array}$ & 215 & 77.6 & $7.30 \pm 2.47$ & $7.50 \pm 1.65$ & $11.63 \pm 2.68$ & $16.99 \pm 3.34$ & $43.44 \pm 6.49$ \\
\hline $\begin{array}{l}\text { Expenditure less than } \\
\text { income }\end{array}$ & 14 & 5.1 & $7.85 \pm 3.34$ & $7.14 \pm 1.79$ & $11.57 \pm 2.59$ & $15.92 \pm 3.26$ & $42.50 \pm 7.24$ \\
\hline Test and $p$ & & & $\begin{array}{l}\mathrm{KW}=16.964 \\
\mathbf{p}=\mathbf{0 . 0 0 0}\end{array}$ & $\begin{array}{l}K W=1.646 \\
p=0.439\end{array}$ & $\begin{array}{l}K W=0.586 \\
p=0.746\end{array}$ & $\begin{array}{l}\mathrm{KW}=7.008 \\
\mathbf{p}=\mathbf{0 . 0 3 0}\end{array}$ & $\begin{array}{l}\mathrm{KW}=0.564 \\
p=0.754\end{array}$ \\
\hline \multicolumn{8}{|l|}{ Love towards Nursing } \\
\hline Yes & 243 & 87.7 & $6.95 \pm 2.51$ & $7.55 \pm 1.67$ & $11.55 \pm 2.68$ & $17.21 \pm 3.29$ & $43.28 \pm 6.37$ \\
\hline No & 34 & 12.3 & $7.76 \pm 3.22$ & $7.50 \pm 1.92$ & $11.82 \pm 2.96$ & $16.52 \pm 3.67$ & $43.58 \pm 7.52$ \\
\hline Test and $p$ & & & $\begin{array}{l}U=3582.000 \\
p=0.206\end{array}$ & $\begin{array}{l}U=4123.000 \\
p=0.985\end{array}$ & $\begin{array}{l}U=4026.000 \\
p=0.809\end{array}$ & $\begin{array}{l}U=3615.000 \\
p=0.236\end{array}$ & $\begin{array}{l}U=4033.500 \\
p=0.823\end{array}$ \\
\hline
\end{tabular}

U: Mann-Whitney Test; KW: Kruskal-Wallis Test. 
Table 4: Min-Max scores obtained from SCBSNS subscales and distribution of score averages $(\mathrm{N}=277)$.

\begin{tabular}{|l|l|l|l|}
\hline SCBSNS & Min-Max scores that can be obtained & Min-Max scores obtained & $\overline{\mathbf{x}} \pm$ SS \\
\hline Being Optimistic & $0-16$ & $1-15$ & $7.05 \pm 2.61$ \\
\hline Transference & $0-12$ & $2-12$ & $7.55 \pm 1.70$ \\
\hline Problem Solving & $0-24$ & $4-20$ & $11.58 \pm 2.71$ \\
\hline Avoidance & $0-24$ & $5-24$ & $17.24 \pm 3.62$ \\
\hline Total & $0-76$ & $24-60$ & $43.32 \pm 6.51$ \\
\hline
\end{tabular}

It was found that the average score obtained from SCBSNS was $43.32 \pm 6.51$ which was at a medium level. When it comes to the average score obtained from the subscales of SCBSNS, the average score for being optimistic was found to be $7.05 \pm 2.61$ while the average score for transference was found to be $7.55 \pm 1.70$. The average score was $11.58 \pm 2.71$ for the problem-solving subscale while the average score was $17.24 \pm 3.62$ for the avoidance subscale (Table 4).

\section{Discussion}

In the research which was carried out to determine Covid-19 perception status and coping behaviours of senior nursing students, the results that were obtained were discussed with the related literature. Approximately half of the students who participated in the study think that the Covid-19 virus is a biological weapon. In a study, it was concluded that healthcare professionals considered Covid-19 as a war [23]. In fact, it is not clear yet whether Covid-19 is a biological weapon or a result of zoological mutation and amplification [24]. However, events experienced by individuals are as important as their thoughts about the events [25]. Students' thinking of Covid-19 as a biological war can cause their stress levels to increase. In the literature, studies on whether the Covid-19 virus is created as a biological weapon could be found [26]. In a study conducted by Ari and Kanat, it was stated that although the information that the Covid-19 virus emerged as a result of natural selection is correct, teacher candidates think of the Covid-19 virus as a biological weapon. It has been determined that eliminating the information impurities and the situations that may develop anxiety will be beneficial for psychological health of individuals [27].

The Covid-19 pandemic is, above all, a health crisis. However, this health crisis is rapidly turning into an economic crisis [28]. In this study, the vast majority of students think that Covid-19 will cause economic crises. Even if it is difficult to determine the scale and nature of the Covid-19 pandemic and the associated economic decline, it is predicted that there will be a global decline in poverty and disease issues. In a study conducted with teachers, it was found that teachers' perceptions of the concept of the virus during the Covid-19 pandemic were negative due to many factors involved in their economic problems [29].
In the research, more than half of the students think that traditional medicines are effective for protection against this virus (56.7\%) and that a treatment method will be found within this year (61.4\%). China and some other developed countries are still working on an antiviral vaccine for Covid-19. In our country and some other countries, passive immunization is also being studied as a treatment method [30]. Traditional, complementary, and alternative medicine practices are widely used in the prevention, diagnosis, and treatment of various diseases in the world. It can be said that nursing students trust traditional drugs, complementary and alternative medicine practices for Covid-19 treatment. In a study conducted with nursing students, it was found that of the 14 rules established to protect against Covid-19, students mostly followed the hand washing rule and using traditional and complementary medicine practices [31]. In a study conducted with patients with multiple sclerosis, it was found that patients using traditional and complementary medicine practices felt better physically and spiritually [32].

Most of the students who participated in the study (89.9\%) think that Covid-19 improves the hygiene and cleaning culture. In astudy conducted during the Covid-19 pandemic process, most of the participants reported an increased frequency of cleaning at home [33]. In a study conducted in our country, half of the participants stated that they increased the cleaning material stores [34]. The rapid spread of the pandemic and its deathly nature increases individuals' stress related to health and makes them take more precautions regarding hygiene and cleanliness. This research finding is an expected situation. A study conducted with adolescents and their parents found that parents' obsession with cleanliness increased more during the Covid-19 pandemic, and this result is consistent with similar studies in the literature $[35,36]$.

In the research, half of the students (52.7\%) think that the information obtained from social media related to Covid-19 is useful. In a study conducted in our country, it was concluded that the Covid-19 pandemic was the most reported subject and the stress level of most people increased through the news [25]. When people cannot control their stress and their stress level rises, they can believe that these thoughts are correct without questioning their thoughts about the event. At this point, nursing students need to have developed 
critical thinking and health literacy skills. In the epidemic process, the public follows many platforms, both national and international. In particular, the number of people who follow the Twitter accounts of the Minister of Health, Fahrettin Koca and Science Committee has been determined by studies and it has been concluded that the number of people is in majority. The statements of the Minister of Health have been followed both on social media and on television. This situation confirms how much the public needs the explanations of reliable institutions and experts in the media. On the other hand, the spread of false or fake news and the sharing of contradictory information by experts negatively affects the public's confidence in the media during the epidemic [37].

As a result of the measures taken to prevent the spread of the pandemic in our country and the effective intervention of the health system, the number of cases and mortality rates were lower compared to other countries [34]. In the study, half of the students think that the health-related measures taken for Covid-19 are sufficient both in the country $(52.3 \%)$ and in schools $(52 \%)$. Beginning the profession in the health sector, where the level of risk is very high, especially in the pandemic process, may affect the perspective of nursing students related to health measures.

According to the recommendations of the World Health Organization, some personal precautions should be taken for protection against Covid-19 [38]. In this study, $65.3 \%$ of students think that personal measures are protective against Covid-19. This situation, moderate stress levels of the students during the Covid-19 pandemic process may affect nursing students' personal precautions against the disease.

A great majority of the students (89.9\%) stated in the study that they would implement the recommended measures related to Covid-19. In a study conducted after the Covid-19 pandemic, an increase (85-90\%) was observed in behaviors involving preventive measures [24]. In this situation, senior nursing students' stating that they will implement recommended measures related to Covid-19 will contribute positively to their colleagues as well as other individuals or patients with whom they interact.

In a recent study, students' stress levels were found to be high during the Covid-19 pandemic process [39]. In this study, it was determined that nursing students' coping behaviors during the Covid-19 pandemic process were moderate. In a similar study, it was found that the stress levels of nursing students during the covid-19 process were high [12]. The reason for these different findings may be since the studies were conducted in different sample groups. In a similar study with nursing students, students' anxiety levels were found moderate during the Covid-19 outbreak [40]. A quantitative study conducted with nursing students during the pandemic found high levels of anxiety [12]. It is stipulated that the variability of anxiety levels in these studies conducted with students is due to the difference in the regions in which students live and the time of data collection.

In this study, it was found that nursing seniors with incomes less than expenses had a higher lower size of Nursing Students' Coping Behaviours of Stress optimism, while students with incomes more than expenses had a higher lower size of Nursing Students' Coping Behaviours of Stress avoidance. In a study conducted with nursing students, it was found that students whose income exceeds their expenses take a more optimistic approach to deal with a stressful situation. The possible reason for this situation is the fact that these students do not experience financial difficulties causes them to have a more positive outlook on life [41]. During the Covid-19 pandemic, students experienced severe anxiety due to economic uncertainties, fear for themselves and their families' health, and changes in their educational processes. They used various strategies to deal with this anxiety process they experienced. Understanding the coping strategies that students develop during this process can lead to develop more functional and effective intervention methods [40].

In this study, being optimistic, transference, and problem-solving levels were found to be moderate while avoidance level was above average in nursing students' coping behaviours during the Covid-19 pandemic. In a study conducted with nursing students using the same measurement tool before the Covid-19 pandemic, the level of avoidance was found to be below the average [42]. Similarly, being optimistic, transference, and problem solving levels were found to be above average while avoidance level was below average in a study conducted with university students before the Covid-19 pandemic [43]. This difference suggests that the Covid-19 pandemic has changed the behaviors of nursing students for coping with stress.

\section{Limitations of Study}

The limitation of our study is related to the sample. Our sample does not include all senior nursing students. The results of this study are limited to the students' selfreported opinions.

\section{Conclusion}

Senior nursing students think that Covid-19 is a biological weapon, it will lead to economic crises; however, it positively affects the culture of social hygiene. Besides, it was determined that personal measures for protection against the Covid-19 were important for nursing students, and their possibility to apply these measures was high. During the Covid-19 pandemic, students' behaviors to cope with stress were moderate, but their behaviours to cope with stress changed. 


\section{Inferences for Nursing Practices}

Since Covid-19 perception may affect the stress experienced by nursing students, studies examining these features are required. Nursing students should be provided with training programs regarding Covid-19 that will strengthen their ability to cope with stress. Besides, senior nursing students may be offered psychoeducational and psychological counselling to strengthen their ability to cope with stress during the Covid-19 pandemic process.

Globally, the fight against Covid-19 is still ongoing. In order to overcome this process successfully, the entire society must take the necessary measures. In this process, nurses have a great responsibility to increase the awareness of Covid-19 in the society and to give the information that the fake news and false information circulating around are not respected. Nurses can help by sharing real news and accurate information with communities. Additionally, the fact that nurses are leaders to nursing students who are always in the process of active learning with them will also allow students to easily cope with this situation in the event of a crisis [44].

\section{Acknowledgments}

I would like to thank all the students for their participation in the research.

\section{Conflict of Interest Statement}

The authors declare no conflicts of interest with respect to the research, authorship and/or publication of this article.

\section{Funding}

No funding had been needed for this survey.

\section{Authors Contributions}

Study design, Manuscript drafting, Statistical analyses, Data collection.

\section{References}

1. Wang C, Horby PW, Hayden FG, Gao GF (2020) A novel coronavirus outbreak of global health concern. Lancet 395: 470-473.

2. Cucinotta D, Vanelli M (2020) WHO declares Covid-19 a pandemic. Acta Biomed 91: 157-160.

3. Taylor S (2019) The psychology of pandemics: Preparing for the next global outbreak of infectious disease. Cambridge Scholars Publishing, UK.

4. Hawryluck L, Gold WL, Robinson S, Pogorski S, Galea S, et al (2004) SARS control and psychological effects of quarantine, Toronto, Canada. Emerg Infect Dis 10: 12061212.

5. Tuncay FE, Koyuncu E, Özel Ş (2020) A review of protective and risk factors affecting psychosocial health of healthcare workers in pandemics. Ankara Med J 2: 488-504.

6. Nickell LA, Crighton EJ, Tracy CS, Al-Enazy H, Bolaji Y, et al. (2004) Psychosocial effects of SARS on hospital staff: Survey of a large tertiary care institution. CMAJ 170: 793798.

7. Marjanovic Z, Greenglass ER, Coffey S (2007) The relevance of psychosocial variables and working conditions in predicting nurses' coping strategies during the SARS crisis: An online questionnaire survey. Int J Nurs Stud 44: 991-998.

8. Huang JZ, Han MF, Luo TD, Ren AK, Zhou XP (2020) Mental health survey of 230 medical staff in a tertiary infectious disease hospital for Covid-19. Zhonghua Lao Dong Wei Sheng Zhi Ye Bing Za Zhi 38: 192-195.

9. Tezel A, Akpınar RB, Yurttaş A, Çelebioğlu A (2008) Hastalar Erkek Hemşireleri Kabul Edecekler Mi? Türkiye Klinikleri Tıp Etiği-Hukuku-Tarihi Dergisi 16: 13-18.

10. Çevirme A, Aylin K (2020) Covid-19 pandemia and its reflections to nursing profession. Eurasian Journal of Researches in Social and Economics 7: 46-52.

11. Karasu $F$ (2020) An intensive care nurse in the forefront of the epidemic while increasing cases of Covid-19. Journal of Critical Care Nursing 24: 11-14.

12. Savitsky B, Findling Y, Ereli A, Hendel T (2020) Anxiety and coping strategies among nursing students during the Covid-19 pandemic. Nurse Educ Pract 46: 102809.

13. Kürtüncü M, Kurt A (2020) Problems experienced by nursing students about distance education in the period of Covid-19 pandemic. Journal of Eurasian Social and Economic Research 7: 66-77.

14. Cao W, Fang Z, Hou G, Han M, Xu X, et al. (2020) The psychological impact of the Covid-19 epidemic on college students in China. Psychiatry Res 287: 112934.

15. Wang C, Cheng Z, Yue XG, McAleer M (2020) Risk management of Covid-19 by universities in China. J Risk Financial Manag 13: 36.

16. Lee J (2020) Mental health effects of school closures during Covid-19. Lancet Child Adolesc Health 4: 421.

17. Wong JGWS, Cheung EPT, Cheung V, Cheung C, Chan MTY, et al. (2004) Psychological responses to the SARS outbreak in healthcare students in Hong Kong. Med Teach 26: 657-659.

18. Elrggal ME, Karami NA, Rafea B, Alahmadi L, Al Shehri AA, et al. (2018) Evaluation of preparedness of healthcare student volunteers against Middle East respiratory syndrome coronavirus (MERS-CoV) in Makkah, Saudi Arabia: A crosssectional study. Z Gesundh Wiss 26: 607-612.

19. Loh LC, Ali AM, Ang TH, Chelliah A (2006) Impact of a spreading epidemic on medical students. Malays J Med Sci 13: $30-36$.

20. Aslan H, Pekince H (2021) Nursing students' views on the covid-19 pandemic and their percieved stress levels. Perspect Psychiatr Care 57: 695-701.

21. Sheu S, Lin HS, Hwang SL (2002) Perceived stress and physio-psycho-social status of nursing students during their initial period of clinical practice: The effect of coping behaviors. Int J Nurs Stud 39: 165-175.

22. Karaca A, Yildirim N, Ankarali H, Açikgöz F, Akkuş D (2015) Turkish adaptation of perceived stress scale, bio-psychosocial response, and coping behaviours of stress scales for nursing students. Journal of Psychiatric Nursing 6: 15-25.

23. Kalra A, Michos ED, Chinnaiyan KM (2020) Covid-19 and the healthcare workers. Eur Heart J 41: 2936-2937. 
24. Bobdey S, Ray S (2020) Going viral - Covid-19 impact assessment: A perspective beyond clinical practice. J Mar Med Soc 22: 9-12.

25. Metin A, Çetinkaya A (2020) According to cognitive model possible effects of coronavirus pandemic on human psychology. Journal of Current Researches on Social Sciences 10: 231-244.

26. Dehghani A, Masoumi G (2020) Could SARS-CoV-2 or Covid-19 be a biological weapon? Iran J Public Health 49: 143-144.

27. Ari AG, Kanat MH (2020) Covid-19 (koronavirüs) üzerine öğretmen adaylarinin görüşleri. Yüzüncü Yil Üniversitesi Sosyal Bilimler Enstitüsü Dergisi, 459-492.

28. McKee M, Stuckler D (2020) If the world fails to protect the economy, Covid-19 will damage health not just now but also in the future. Nat Med 26: 640-642.

29. Çetin NI, Timur S, Pehlivan H (2021) Fen Bilimleri Öğretmenlerinin Covid-19 Pandemi Sürecinde "Virüs" Kavramina Yönelik Metaforik Algilarinin Incelenmesi. International Journal of Eurasia Social Sciences 12: 47-59.

30. Özdemir Ö, Pala A (2020) Diagnosis, treatment and prevention methods of pediatric Covid-19 infection. Journal of Biotechnology and Strategic Health Research 1: 14-21.

31. Işik MT, Can R (2021) Bir Grup Hemşirelik Öğrencisinin Covid-19 Riskine Yönelik Koruyucu, Geleneksel ve Tamamlayici Tip Uygulamalari. Mersin Üniversitesi Tip Fakültesi Lokman Hekim Tip Tarihi ve Folklorik Tip Dergisi 11: 94-103.

32. Çelik RGG, Öztürk M, Altin S, Köseoğlu M, Sariahmetoğlu H, et al. (2019) The prevalence of alternative-complementary therapies in patients with multiple sclerosis. Turk $\mathrm{J}$ Neurol 25: 153-158.

33. Gharpure R, Hunter CM, Schnall AH, Barrett CE, Kirby $A E$, et al. (2020) Knowledge and practices regarding safe household cleaning and disinfection for Covid-19 prevention - United States, May 2020. MMWR Morb Mortal Wkly Rep 69: 705-709.
34. Karataş Z (2020) Social impacts of Covid-19 pandemic, change and empowerment. TUSHAD 4: 3-17.

35. Göl-Güven $M$, Şeker V, Erbil F, Özgünlü $M$, Alvan $G$ (2020) Covid-19 pandemisinin aile yaşantisina yansimalari Rapor-2.

36. Lai J, Ma S, Wang Y, Cai Z, Hu J, et al. (2020) Factors associated with mental health outcomes among health care workers exposed to coronavirus disease 2019. JAMA Netw Open 3: e203976.

37. Çobaner AA (2021) Covid-19 sürecinde değişen sağlik/risk algisi ve medya tüketim pratikleri.

38. World Health Organization (2020) Rational use of personal protective equipment (PPE) for coronavirus disease (Covid-19): Interim Guidance.

39. Rehman U, Shahnawaz MG, Khan NH, Kharshiing KD, Khursheed M, et al. (2021) Depression, anxiety and stress among indians in times of Covid-19 lockdown. Community Ment Health J 57: 42-48.

40. Temiz Z (2020) Nursing students' anxiety levels and coping strategies during the Covid-19 pandemic. Int Arch Nurs Health Care 6: 150

41. Yilmaz $M$, Yaman Z, Erdoğan S (2017) Öğrenci hemşirelerde stres yaratan durumlar ve baş etme yöntemleri. Mersin Üniversitesi Sağlik Bilimleri Dergisi 10: 88-99.

42. Bozyilan E (2018) The effects of the nursing students' sport habits on the stress perceived, bio-psycho-social response and coping behaviours of stres. Gaziantep University, Gaziantep.

43. Durmuş M, Gerçek AA (2017) Research on assessing the factors affecting perceived stress situations, biopsychological social situations and coping behaviors of stress in university students. The Journal of Academic Social Science 5: 616-633.

44. Nashwan AJ, Mohamed AS, Kelly DR (2020) Nursing education in the emergence of Covid-19. Open Journal of Nursing 10: 595-597. 